\title{
COMMUNITY DEVELOPMENT
}

\section{HEALTH BY THE YEAR 2000 - HEALTH EDUCATION AND THE COMMUNITY NURSE}

\author{
MAVIS L. ARTHUR \\ TECHNIKON WITWATERSRAND
}

\section{OPSOMMING}

Vandag se belangrikste gesondheidsprobleme kan aan 'n kennisgebrek en gewoontes wat gesondheid nadelig beinvloed, toegeskryf word. Om Gesondheid vir almal teen die jaar 2000 te bereik sal die moontlikhede van gesondheidsvoorligting ten volle ontgin moet word.

Die gesondheidsvoorligter moet die kultuur en omstandighede van die betrokke gemeenskap ken en besef dat die bybring van kennis nie genoeg is om gedragsverandering teweeg te bring nie. Laasgenoemde is 'n moeilike taak, maar wel moontlik indien twee belangrike feite in gedagte gehou word, naamlik dat leer 'n aktiewe proses is en dat slegs dit wat op 'n gegewe tydstip van belang is, geleer word. Die voorligter moet dus leermetodes gebruik wat die leerder aktief betrek en moet die behoeftes van die leerder noukeurig bepaal.

Die gemeenskapsverpleegkundige is in 'n sleutelposisie om gesondheidsvoorligting op alle vlakke van siektevoorkoming te gee. Sy skakel met die gemeenskap voordat probleme ontstaan en het toegang tot die huis waar die fondament van goeie gesondheid gelê word.

Nuwe gesondheidsvoorligtingsinisiatiewe is nodig om individue en gesinne vir die spanning van die moderne samelewing voor te berei.

\section{HEALTH EDUCATION - THE NEED TO MAKE IT WORK}

$T^{t}$ is increasingly apparent that the major health problems in the world today - ranging from malnutrition and communicable diseases; many forms of mental ill-health and cardiac conditions; accidents and alcoholism, are primarily attributable to unsatisfactory living conditions, lack of knowledge and harmful practices on the part of individuals, families and communities. Advances in the field of science and technology can do no more towards the promotion of the health of the population unless it is accompanied by fundamental changes in the way of life and behaviour patterns of the people themselves.

The challenge to the health worker lies in his ability to find some means of weaving the discoveries of science into the fabric of the daily life of the people concerned. Thus the World Health Organisation's target of Health for All by the Year 2000 can only be realised if the potential inherent in health education is fully exploited. People must be persuaded to adopt and sustain healthy practices, to use the health services available to them wisely and judiciously, to take their own decisions, both individually and collectively and so improving their environment and health status.

All are agreed on the need for health education as a tool to effect the required changes and on the role that education plays in community involvement and development. In practice however, it seems that many still pay lip service to the need for the individual to assume responsibility for his own health care and the relevance of health education in this regard.

Far too frequently health professionals move into a community armed with predetermined procedures and practices related to their own cultural equation of medicine, health, illness and treatment. They present the people with a set of do's and don'ts based on what they see as the community's needs

\section{THE COMMUNITY SETTING}

Health education involves an understanding of the setting in which people live and work. This requires time. The educator must be prepared to be educated, as the field worker must have a sound understanding of the setting in which he works before being able to give appropriate health education.

The way in which an individual receives and acts upon information is likely to be influenced by circumstances - his friends, family and community, the environment in which he lives and works as well as the social and political events which affect his life-style. To cite an example: a simple health message, relating to diet which is regarded as logical and economical by the health profession, has little chance of success if it is seen as a problem by the family, scorned by friends, difficult to fulfill at work, is governed by socio-economic factors which affect the availability of foodstuffs or opposes firmly entrenched traditional beliefs about the role and function of food.

Time is also required to build a relationship with a specific community so that the educator has a reasonable chance of being heard. The community needs to know that the health worker cares about its welfare, has integrity and possesses knowledge that may be helpful.

Because of the time needed for successful health education the policy of constantly rotating community nurses from one area to another interferes with the process of education. A change should thus be undertaken only after serious consideration. 
THE RELATIONSHIP BETWEEN KNOWLEDGE AND BEHAVIOURAL CHANGE

The traditional belief that ignorance is the main hurdle to overcome in disease prevention and that people will accept change with enthusiasm if only they are educated is now being challenged. The extent to which behaviour is influenced by knowledge is limited. Compare, for example, the knowledge that nurses have about the dangers of smoking and the number who continue to smoke. It is not what we know, but what we want and need; not information, but our habits, actions and the people we are involved with, that are the real agents of change in our lives. The adult in every community has knowledge which forms the basis of his frame of reference and the message of the educator, which the individual is free to accept or reject, is only one of the many alternative solutions to any situation. The focal point in health education should therefore be behavioural change and it should be the type of education which encourages people to act on their own behalf.

To affect behaviour change is a formidable task, but it is not hopeless provided that two principles are accepted. These are firstly that learning is an active process and takes place as a result of the individual's own efforts and secondly, that people are only prepared to pay attention and become involved in those events which are meaningful to them at that particular moment.

Bearing these two points in mind, we should carefully examine the widespread practice whereby a series of general health education programmes are prepared in advance by nursing staff and repeated at regular intervals for those attending out-patient departments, ante-natal and child health clinics. These groups are frequently captive audiences and little attention is paid to the specific circumstances of the individual members of the group. All the mothers at a child health clinic are for instance, not necessarily interested in potty training. Furthermore, the educational methods used are often those whereby information is given rather than those which involve the individual in an active learning situation.

While bearing the above two learning principles in mind the well known who, what, why, how, where and when of planning must also be applied. Considering the who, what and why of planning, it is always wise to remember that members of the community are partners in the process of education and that the support of both formal as well as informal leaders in die group are cru- cial to be success of any project. The educator must find out what various groups in the community need to know or do, rather than teach what he feels they ought to know or do. This approach gives the educator an opportunity to state his own concerns as well as encouraging active co-operation and participation in setting educational goals.

Since the object of education is to change behaviour, objectives of any educational programme should be expressed in the form of behavioural objectives for example to run two kilometres as opposed to exercising more frequently. This policy has the further advantage that the objectives are measurable and form the basis of accurate evaluation.

Methods which place the learner in an active situation are more likely to be effective than those which do not. This generally implies more and smaller target groups which entails a great deal more initial organisation, but with a number of important advantages. Firstly, the programme may be developed to meet the individual needs of each member of the group. Secondly, the learner is given the opportunity of examining proposed changes and procedures and determining whether they are feasible in terms of cost and life-style and if not, he is able to work out how they can be modified to fit in with the life-style of all concerned. Thirdly, this type of learning situation enables the individual to test the degree of social and psychological support he will receive in the wider community if he makes certain changes in his behaviour pattern.

The more learning is considered to be an active process, primarily controlled by the learner, unique to that individual and the consequence of experience, the more one becomes aware of over-reliance on mass-media. One wonders whether these aids, especially those that are mass produced, are tailor-made to fit the varying perceptual patterns of different population groups, or indeed, the different socio-economic groups within a single community.

This does not mean that the mass media do not play a role in support of health and health education. It provides people with essential information and creates the base necessary for health change. The degree to which this information is translated into action will however be determined by how successfully it is integrated into programmes in the field. A greater integration between the media and personal health services is required. The nurse is in a position to bridge this gap in both hospital and community services. She is able to help people interpret and examine information and to develop new ways of thinking, acting and behaving. Evaluation, a much quoted, but frequently neglected part of any educational programme is vital if health education is to be a dynamic service which achieves its predetermined objectives.

\section{THE CHALLENGE AND SCOPE OF HEALTH EDUCATION}

Health education is the responsibility of many professions. The community nurse, who is in constant contact with members of the community is however in a key position to conduct health education and initiate community participation throughout the continuum of primary, secondary and tertiary levels of disease prevention. Moreover, she is the one member of the health team who has access to homes before problems occur.

The foundations for health are laid in the home where individuals develop their beliefs about the causes of disease and its treatment and learn about their bodies and how to look after them with regards to food, hygiene, exercise and other aspects. Habits and practices which play such an important role in the determination of the future health of the community are also developed in the home.

The community nurse in her role as educator, is able to bring about a change in attitudes. She can help people realise that they must do certain things if general standards of health are to be improved, for example to exercise more or install sanitary latrines. She is also in a position to anticipate problems which may occur at the normal critical periods throughout the life-span of the individual and family and intervene timeously. At such times people are more ready to pay attention to certain key issues; to enquire about and form solutions to new problems and changing circumstances

The question now arises whether nurses in the community health field ${ }^{\circ}$ fully exploit the opportunities which exist for health education.

Prospective and early parenthood finds young adults particularly receptive to health messages. It is no chance measure that maternal and child health services are high on the World Health Organisation's list of health priorities. Influences brought to bear in this sphere can measurably affect not only the physical health, but also the social and emotional health of future generations. Evidence of the need for knowledge and skills related to child bearing 
as well as child rearing techniques is revealed in the many letters to journals and newspapers. This indicates that opportunities for health education are all too often neglected by health personnel. Programmes may be conducted in the ante-natal clinics of general hospitals, but private patients are neglected to a great extent. Many opportunities for potential intervention are lost through the absence of regular routine home-visiting as well as a lack of co-ordination between hospital and community services.

Small selected target groups for health education on topics of common interest, held at regular intervals, will help people acquire the skills they need. It may also generate the necessary impetus for the group to develop and initiate its own programmes and involve more and more members of the community.

There are many opportunities for education in play groups, as well as mother and toddler groups. An interest in the normal development of the child needs to be encouraged. This would serve to make the child more interesting to the parents, give them a better understanding of his needs and provide them with the skills for meeting these needs. The foundation for mental health are laid during this period.

Health teaching should be an integral part of the education of all children and adolescents, for the attitudes and values which will determine future health patterns are formed during this period. Too little health education is provided in schools and too often, when given, is in the educational format of do's and don'ts. There is a need to develop a positive approach for healthy living among children by doing away with the shall not approach and emphasising those actions which contribute to good health. Children are also quite capable of listing, in order of priority, the health subjects in which they are interested.

Although children are more readily influenced than adults and may also act as agents of change in the home. they cannot be exposed to health education in isolation. Programmes running in school should be reinforced by those involving parents and the wider community.

During adolescence, education may be geared towards giving people a better understanding of human development, social roles and the responsibility of the individual towards himself, his family and the community. In an increasingly complex society, the alternative choices of behaviour are so numerous that guidance by well-informed professionals is invaluable.

The necessity of education in the work situation is increasingly apparent and a major responsibiliy of the occupational health nurse. Middle age, a stage of development which presents with many problems, is grossly neglected by the health services and almost entirely overlooked when it comes to health education.

Much may be achieved for the aged through the agency of the health services as illustrated in the article Community involvement - it can be done in this journal. However, due to an increasing proportion of elderly in the community and the fact that their pro- blems tend to be more tangible many health authorities appear to be concentrating resources and services on curative aspects at the expense of promotive and preventive services, including health education, for the younger age groups - hence reducing their potential for reaching a healthier and more productive old age.

Education is also an ingegral part of treatment when ill-health occurs. It ensures that the patient understands his responsibility towards his own recovery and may also play a role in preventing other members of the family from developing a similar condition.

\section{CONCLUSION}

New initiatives in health education are required on the part of the community nurse to help and to prepare individuals and families to meet the pressures of living in a modern society and to assume responsibility for their own health.

\section{BIBLIOGRAPHY}

1. Gunaratne, V.T.H. Health for all by the year 20000 : the role of health education. International Journal of Health Education. Supplement to Vol. 23 No. 1, January March 1980 .

2. Horn, D. A model for the study of personal choice health behaviour. International Journal of Healih Educa tion Vol. 19 No. 2 April - June 1976.

3. Health Education Supplement. Nursing Times, Vol. 73 No. 25, 23 June 1977

4. Green, L.W. et al. Guidelines for health education in maternal and child health. International Journal of Heallh Education. Supplement to Vol. 21 No. 3, July September 1978 .

5. Thomson. W Health education: let's start at school. Nursing Times Vol. 74 No. 41, 12 October 1978.

6. Guilbert. J.J. Educational handbook for health person nel. Offset Publications No. 35. World Health Organi sation. Geneva. 1977.

\section{BREASTFEEDING WORLD HEALTH ORGANISATION. GENEVA. 1979.}

\section{(OBTAINABLE FROM THE PUBLICATION SEC- TION, SOUTH AFRICAN NURSING ASSOCIATION AT R1,10)}

If used selectively as reinforcement after health education has been given to the mother by the nurse or other health educator, this brochure contains invaluable information for the layman and mother with regard to:

- the natural course of breastfeeding;

- conditions that help the mother to breastfeed successfully;

- various other situations that need special attention such as:
- engorged breasts and breast abscesses;

- suckling difficulties;

- babies with difficulties.

Attention should be drawn to the fact that the information regarding breastfeeding and child spacing given in the brochure on page 11 has proven itself to be most unreliable. If the information were to be distributed in South Africa it would cause much confusion in the minds of clients as well as nursing personnel. The advice regarding the use of a diaphragm or foam is not practical for the target population for which it is intended.

Furthermore, injectable type of contraception viz Depoprovera or NUR-isterate, have no adverse effect whatsoever on lactation according to literature available from the Department of Health, Family Planning Program. Private Bag X88, PRETORIA 0001.

I. THORBURN 